\title{
An Ecological Assessment for Water Quality of Some Water Bodies in Koysenjaq-Erbil, Iraq.
}

\author{
Janan Jabbar Toma, Yahya Ahmad Shekha and Yadi Omar Mustafa Al-Barzingy \\ Department of Environmental Sciences, College of Sciences, University of Salahaddin, Erbil-Iraq.
}

\begin{abstract}
Water `assessment and algal composition study was conducted near Koysenjaq district for nine sites including (4) springs and (5) streams. Monthly water samples collected from April-2013 to March-2014 and 15 physico-chemicals parameters and algal content were analyzed. Generally, $\mathrm{pH}$ of water tend to be in alkaline side of neutrality. Mean values of electrical conductivity ranged between $272-441 \mu \mathrm{s} . \mathrm{cm}^{-1}$ in January and July respectively. Total hardness extended from hard to very hard water. Cation arranged in order as follows: $\mathrm{Ca}>\mathrm{Mg}>\mathrm{Na}>\mathrm{K}$. Higher mean value of ammonium recorded in site 6 was $14.8 \mu \mathrm{g} \mathrm{N} \cdot \mathrm{NH}_{3} \cdot \mathrm{l}^{-1}$, and minimum value of nitrite was $0.68 \mu \mathrm{g}$ $\mathrm{N} . \mathrm{NO}_{2} \cdot \mathrm{l}^{-1}$ in site 6 . Mean values of phosphate ranged between $\left(0.82-4.5 \mu \mathrm{g}\right.$ P-PO $\left.4 . \mathrm{I}^{-1}\right)$. Highest value of dissolved oxygen were observed in sites 7, 8 and 9, while the minimum value of biochemical oxygen demand recorded in site 2 was $0.7 \mathrm{mg} . \mathrm{l}^{-1}$. A total 73 species of algal species were identified of which belong to Bacillariophyceae ( 25 species), Cyanophyceae (23 species), Chlorophyceae (16 species), Euglenophyceae (4 species), Charophyceae and Xanthophyceae (2 species for each one) and 1 species belong to Rhodophyceae. Multivariate statistical techniques results revealed that water quality of the monitored water bodies were influenced by many pollution sources including the geological formation of the area, agricultural activities and effluent of domestic sewage water.

[DOI: $10.22401 / \mathrm{JNUS} .21 .2 .18]$
\end{abstract}

Keyword: Water quality, springs, streams, multivariate statistical analysis, Koysenjaq.

\section{Introduction}

Water is a very important Grace for the environment, the most important to maintain life and it is required in almost all humanitarian activities. Drinking, domestic use, agriculture, industries, energy production, navigation, and entertainment. The site of Iraq within the Middle East with an area of 433,970 $\mathrm{K}^{2}$, where the number of souls about 35 million people [1]. Many countries are concerned with the presence, uses, security and management of water sources. The evaluation of water quality has become an important issue, especially with an awareness that freshwater will be a rare resource in the future [2]. Water quality is the physical, chemical and biological characteristics of water, it is an assessment of water condition relative to the requirements of human need [3]. The term of water quality was developed to supply an indicator of how suitable the water is for different living consumption and is generally used in various scientific works related to the necessities of sustainable management [4]. However, water quality in many rivers around the world has deteriorated significantly may be due to human activities in the past three decades [5]. River regarded as an important source of inland water resources for human. In the past, social, economic and political development has been linked to the extent to which freshwater is available and distributed in river systems [6 and7]. The climate change in recent years has an important effect on the water quality of rivers of the world in terms of changing patterns of rainfall and increased evaporation rates as a result of high temperature, especially rivers located in arid and semi-arid zones [8 and 9].

Multivariate statistical methods are useful tools for assessment environmental status, identified sources of water pollution, provide valuable ways for water resources management and introduce solutions for pollution control [10, 11, and 12]. Factor analysis (FA) and Cluster analysis (CA) are more widely used statistical analysis for environmental topics in recent years [13, 14], through drawing out meaningful conclusions from data obtained in analysis of water quality.

For further increasing our knowledge, this investigation was conducted in order to evaluate water quality and algae identification in the area which may be regard as the first 
attempt for survey and monitoring some water bodies in Koysenjaq district.

\section{Materials and Methods}

\section{Samples collection and analysis}

Samples collection were done twelve times at monthly intervals pattern during (April2013 to March-2014). The selected sites include four springs (S1, S2, S4 and S5) and five streams in north-east of Koesenjaq district, Erbil- Iraq as illustrated in Fig.(1). Water samples collected by using stopper fitted polyethylene bottles and refrigerated at $4^{\circ} \mathrm{C}$ in order to be analyzed as soon as possible to avoid unpredictable changes in characteristic of water according to standard procedures [15]. Electrical conductivity and $\mathrm{pH}$ were measured in situ using portable measuring devices (PH-EC-TDS meter, HI 9812, Hanna instrument). The physiochemical properties of water samples were measured and performed on the same day of sampling, and analyzed for physicochemical parameters using following procedures. Alkalinity and acidity were measured by titration method as described by [15]. Total hardness and calcium calculated by EDTA titrimetric method as described by [15]. Azide modification of the classical Winkler procedure was used to measure dissolved oxygen, biochemical oxygen demand $\left(\mathrm{BOD}_{5}\right)$. Sodium and potassium cations were determined by Flame Emission Photometer method. The Mohr method was used for determination of chloride content as described in [16]. Nitrite and ammonium measured by spectrophotometer method as noted by [17]. Reactive phosphorus was determined by using ascorbic acid reduction method as mentioned by [17]. Algal identification carried out by using appropriate identification text books [18, 19 and 20].

\section{Statistical analysis}

The data set of monitored surface water was subjected to multivariate statistical methods: Dendogram (Cluster analysis, CA) and Factor analysis (FA), by using SPSS 22 program. PCA/FA was applied for the normalized data set through examine their suitability by using Kaiser Meyor Olkin (KMO) and Bartlett's test. Eigen values higher than 1 indicated that PCA (Principal
Component Analysis) may be useful. Bartlett's test explained if correlation matrix is an identity matrix, which would indicate variables are unrelated $[11,21]$. On the other hand, hierarchial agglomerative CA was performed by means of Wards method for normalized data set, using Euclidean distance as a measure of similarity [22, 23].

\section{Results and Discussion}

The mean values of physico-chemical variables of studied inland water bodies were given in the Table (1). The results showed that the $\mathrm{pH}$ ranged from (6.8-7.3) in sites, and (6.67.3 ) in months indicating that the water sample are almost sub- neutral to sub-alkaline in nature. $\mathrm{pH}$ is an important factor that determines the suitability of water for different purposes [24]. The obtained $\mathrm{pH}$ concentration in the current survey was close to $\mathrm{pH}$ values of fresh water [25] and agree with Iraqi published data [26,27] and were in permissible level recommended by the Iraqi [28] and WHO [29] standards for drinking purpose. Generally, high $\mathrm{pH}$ values observed during December to April Fig.(2), this may be due to effects of rainfall and erosion of soil enriched with carbonate ions. 


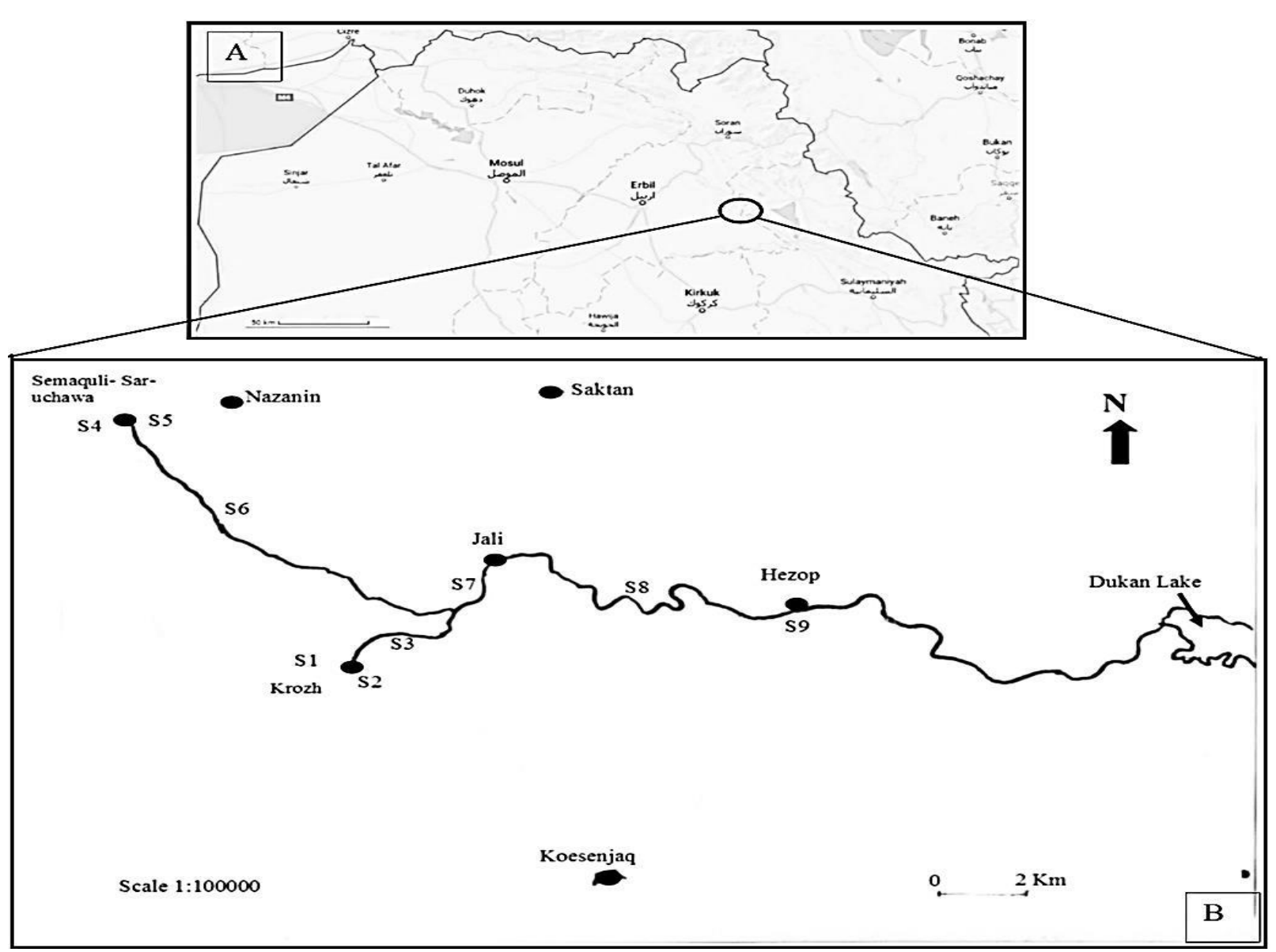

Fig. (1): Maps show: A- Northern part of Iraq, B-Location of studied sites in Koesenjaq district, Erbil- Iraq.

The values of electrical conductivity are related to positive ions concentrations and affect the taste of water that used for drinking purposes and other uses [30]. EC values were varied from 323 to $441 \mu \mathrm{S} . \mathrm{cm}^{-1}$ measured in sites 5 and 9 respectively. The high content values of conductivity can be generated by natural weathering of some type's rocks or may have human sources, for example. Industrial waste and sewage [30]. The results showed that EC values were within the permissible level recommended by the WHO [29] for drinking purpose. The most of observed value of total alkalinity was more than the permissible recommended by the WHO [29] for drinking purpose. On the other hand, same trend of variations were found between alkalinity and $\mathrm{pH}$ during studied period Fig.(2). The normal values of the alkalinity of surface waters are related to carbon dioxide, bicarbonate, carbonate and hydroxide components. These components are characteristic of the source of water and the natural processes happened at any given time
[31]. Higher concentration of acidity value was noted in winter months $21 \mathrm{mg} \mathrm{CaCO} \cdot \mathrm{l}^{-1}$, while lower value was more than $5 \mathrm{mg}$ $\mathrm{CaCO}_{3} \cdot \mathrm{l}^{-1}$. This variations may be due to geological, weathering, soil and human impacts [26]. The measured value of acidity was within the permissible recommended by the WHO for drinking purpose. 
Table (1)

Physico-chemical variables of Koesenjaq water bodies during studied period, all data expressed as mean \pm S.E.

\begin{tabular}{|c|c|c|c|c|c|c|c|c|c|}
\hline \multirow{2}{*}{ Variables } & \multicolumn{9}{|c|}{ Sites } \\
\hline & 1 & 2 & 3 & 4 & 5 & 6 & 7 & 8 & 9 \\
\hline $\mathrm{pH}$ & $6.80 \pm 0.079$ & $6.86 \pm 0.080$ & $6.99 \pm 0.111$ & \begin{tabular}{|c|c}
$6.83 \pm 0.063$ \\
\end{tabular} & $\mid 6.81 \pm 0.084$ & $\mid 6.94 \pm 0.117$ & $7.087 \pm 0.085$ & $7.15 \pm 0.070$ & $7.32 \pm 0.819$ \\
\hline $\mathrm{EC}\left(\mu \mathrm{S}_{\mathrm{S}} \mathrm{cm}^{-1}\right)$ & $363 \pm 24.3$ & $351 \pm 23.1$ & $362 \pm 21.0$ & \begin{tabular}{|l|l|}
$329 \pm 21.9$ \\
\end{tabular} & \begin{tabular}{|l|}
$323 \pm 20.7$ \\
\end{tabular} & $328 \pm 20.3$ & $349 \pm 23.4$ & \begin{tabular}{||c||}
$408 \pm 20.0$ \\
\end{tabular} & $441 \pm 22.0$ \\
\hline $\begin{array}{c}\text { Alkalinity (mg } \\
\left.\mathrm{CaCO}_{3} \cdot \mathrm{l}^{-1}\right)\end{array}$ & $237 \pm 10.6$ & $233 \pm 12.0$ & $233 \pm 9.63$ & $220 \pm 10.2$ & $232 \pm 11.3$ & $226 \pm 10.9$ & $221 \pm 11.8$ & $214 \pm 11.2$ & $211 \pm 8.79$ \\
\hline $\begin{array}{l}\text { Acidity }(\mathrm{mg} \\
\left.\mathrm{CaCO}_{3} . \mathrm{I}^{-1}\right) \\
\end{array}$ & $7.75 \pm 1.41$ & $6.91 \pm 2.28$ & $7.91 \pm 1.78$ & $10.4 \pm 1.85$ & $8.91 \pm 1.47$ & $10.0 \pm 2.13$ & $8.91 \pm 1.27$ & $9.66 \pm 1.59$ & $9.50 \pm 2.09$ \\
\hline $\begin{array}{l}\text { Hardness (mg } \\
\left.\mathrm{CaCO}_{3} \cdot \mathrm{l}^{-1}\right) \\
\end{array}$ & $278 \pm 11.4$ & $298 \pm 13.6$ & $279 \pm 10.1$ & $277 \pm 9.94$ & $278 \pm 12.4$ & $270 \pm 7.39$ & $251 \pm 21.6$ & $276 \pm 11.7$ & $284 \pm 9.57$ \\
\hline $\begin{array}{c}\mathrm{Ca}^{2+}(\mathrm{mg} \\
\left.\mathrm{CaCO}_{3} \cdot \mathrm{I}^{-1}\right) \\
\end{array}$ & $196 \pm 10.4$ & $194 \pm 10.5$ & $191 \pm 11.9$ & $178 \pm 11.9$ & $177 \pm 10.3$ & $175 \pm 8.13$ & $178 \pm 10.3$ & $176 \pm 12.0$ & $180 \pm 15.5$ \\
\hline $\begin{array}{l}\mathrm{Mg}^{2+}(\mathrm{mg} \\
\left.\mathrm{CaCO}_{3} \cdot \mathrm{l}^{-1}\right)\end{array}$ & $81.7 \pm 7.53$ & $103 \pm 13.4$ & $92.4 \pm 9.90$ & $98.4 \pm 9.90$ & $101 \pm 12.2$ & $95.0 \pm 7.73$ & $73.6 \pm 21.9$ & $99.7 \pm 15.5$ & $103 \pm 12.1$ \\
\hline $\mathrm{Cl}^{-}\left(\mathrm{mg} . \mathrm{l}^{-1}\right)$ & $9.38 \pm 0.67$ & $10.2 \pm 0.52$ & $111.4 \pm 0.46$ & $10.7 \pm 0.70$ & $10.4 \pm 0.54$ & $10.0 \pm 0.43$ & $10.3 \pm 0.43$ & $9.92 \pm 0.64$ & $10.4 \pm 0.65$ \\
\hline $\mathrm{Na}^{+}\left(\mathrm{mg} . \mathrm{l}^{-1}\right)$ & $\begin{array}{l}13.6 \pm 1.01 \\
\end{array}$ & $\begin{array}{l}12.4 \pm 1.12 \\
\end{array}$ & $\begin{array}{ll}16.1 \pm 1.33 \\
\end{array}$ & \begin{tabular}{|l|l|}
$7.95 \pm 2.57$ \\
\end{tabular} & $6.49 \pm 0.98$ & $7.96 \pm 2.57$ & $28.3 \pm 4.47$ & $424.9 \pm 5.74$ & $\begin{array}{l}33.8 \pm 7.60 \\
\end{array}$ \\
\hline $\mathrm{K}^{+}\left(\left(\mathrm{mg} \cdot \mathrm{l}^{-1}\right)\right.$ & $1.87 \pm 0.23$ & $2.08 \pm 0.28$ & $2.42 \pm 0.32$ & $1.44 \pm 0.18$ & $1.39 \pm 0.113$ & $3.28 \pm 0.55$ & $3.17 \pm 0.40$ & $4.42 \pm 0.29$ & $3.51 \pm 0.81$ \\
\hline DO $\left(\right.$ mg..$\left.^{-1}\right)$ & $1.96 \pm 0.32$ & $2.12 \pm 0.25$ & $3.75 \pm 0.26$ & $3.36 \pm 0.31$ & $3.85 \pm 0.311$ & $4.47 \pm 3.65$ & 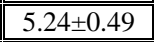 & $4.37 \pm 0.48$ & 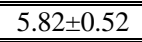 \\
\hline $\mathrm{BOD}_{5}\left(\mathrm{mg} . \mathrm{l}^{-1}\right)$ & $0.73 \pm 0.20$ & $0.57 \pm 0.17$ & $0.86 \pm 0.19$ & $0.97 \pm 0.15$ & $0.94 \pm 0.20$ & $1.13 \pm 0.10$ & $1.24 \pm 0.18$ & $1.00 \pm 0.15$ & $0.91 \pm 0.13$ \\
\hline $\begin{array}{c}\mathrm{NO}_{2}(\mu \mathrm{g} \mathrm{N}- \\
\left.\mathrm{NO}_{2} . \mathrm{l}^{-1}\right) \\
\end{array}$ & $0.86 \pm 0.08$ & $0.84 \pm 0.12$ & $1.06 \pm 0.25$ & $0.83 \pm 0.10$ & $0.70 \pm 0.06$ & $0.68 \pm 0.04$ & $1.34 \pm 0.27$ & $1.12 \pm 0.25$ & $1.53 \pm 0.31$ \\
\hline $\begin{array}{c}\mathrm{NH}_{4}(\mu \mathrm{g} \mathrm{N}- \\
\left.\mathrm{NH}_{4} \cdot 1^{-1}\right) \\
\end{array}$ & $5.95 \pm 1.07$ & $6.39 \pm 1.38$ & $5.83 \pm 0.86$ & $6.62 \pm 1.06$ & $11.1 \pm 2.47$ & $14.8 \pm 3.14$ & $6.26 \pm 0.84$ & $9.12 \pm 2.49$ & $8.93 \pm 2.03$ \\
\hline $\begin{array}{c}\mathrm{PO}_{4}(\mu \mathrm{g} \mathrm{P}- \\
\left.\mathrm{PO}_{4} \cdot 1^{-1}\right) \\
\end{array}$ & $1.64 \pm 0.15$ & $1.52 \pm 0.29$ & $2.43 \pm 0.36$ & $2.20 \pm 0.29$ & $1.99 \pm 0.19$ & $2.27 \pm 0.20$ & $3.27 \pm 0.80$ & $2.73 \pm 0.48$ & $2.96 \pm 0.59$ \\
\hline
\end{tabular}

Total hardness (TH) is another an importance factors of quality of water whether to be used for various purposes. Based on the general guidelines for classification of hardness water as calcium carbonate; 0 to $60 \mathrm{mg} . \mathrm{l}^{-1}$ is classified as soft; 61 to $120 \mathrm{mg} . \mathrm{l}^{-1}$ as moderately hard; 121 to $180 \mathrm{mg} . \mathrm{l}^{-1}$ as hard and more than $180 \mathrm{mg}$. $\mathrm{l}^{-1}$ as very hard [32]. The results shows that most analyzed water samples is very hard. This may be related to high $\mathrm{Ca}^{2+}$ and $\mathrm{Mg}^{2+}$ ions found in all studied sites. These results came in accordance with results that recorded by [33]. Magnesium concentration was lower than calcium ions in all sites and are within the Iraqi standards for drinking purposes. Dissolved calcium and magnesium in water are the two most common mineral that make water "hard" [34]. Calcium and magnesium enter a water supply by leaching from minerals within an aquifer. Common calcium-containing minerals are calcite and gypsum, also some human activities involved with increase calcium by increasing concentration of carbon dioxide which form the carbonic acid that eventually lead to dissolve the bituminous rocks [35]. On the other hand, sodium value ranged from $7-51 \mathrm{mg} .1^{-1}$. The values of $\mathrm{Na}$ were found to be always higher than $\mathrm{K}^{+}$and much less than that of calcium, this comes accordance to that reported by [30]. According to WHO standards [29], the maximum permissible level of sodium is $200 \mathrm{mg} .1^{-1}$. All sites in the studied area lies within this level. [36] stated that potassium ion found in most natural water rarely exceeds $20 \mathrm{mg} .1^{-1}$, corresponding the present investigation, potassium value ranged between 1.4-5 mg. $1^{-1}$. The differences between sodium and potassium values in different sites in this investigation may be considered to the geological and soil formation within Erbil province [36].

The values of $\mathrm{DO}$ and $\mathrm{BOD}_{5}$ were ranged from 1-8.5 mg. $\mathrm{l}^{-1}$ and $0.1-2.8 \mathrm{mg}^{-1} \mathrm{l}^{-1}$ respectively. Sites 7, 8 and 9 characterized by more aeration condition than other sites. Highest DO concentration was recorded during December and March (Fig.3), this may be due to rainfall and low temperature. Unpolluted waters are likely to have a BOD value of $<3 \mathrm{mg} \cdot \mathrm{1}^{-1}$. BOD concentration indicate present or absences of organic matter loaded on water in this area. Therefore, a continuous monitoring is required. 


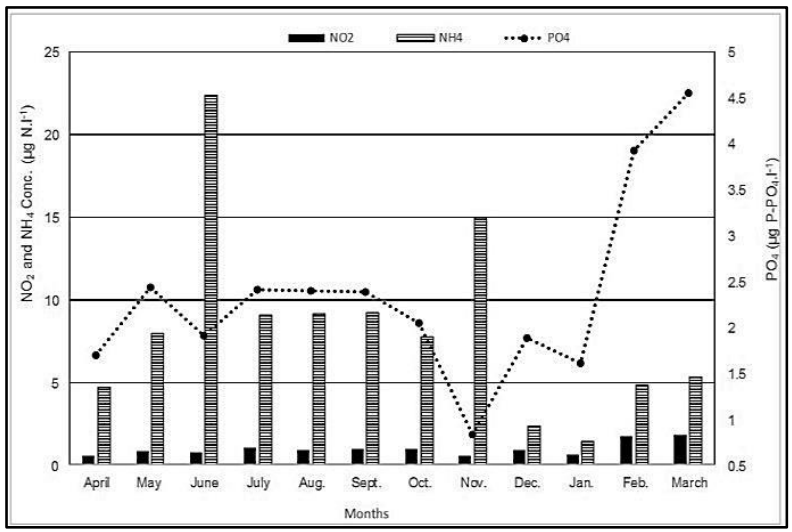

Fig.(2): Variations of $p H$ and alkalinity content of water bodies during studied periods.

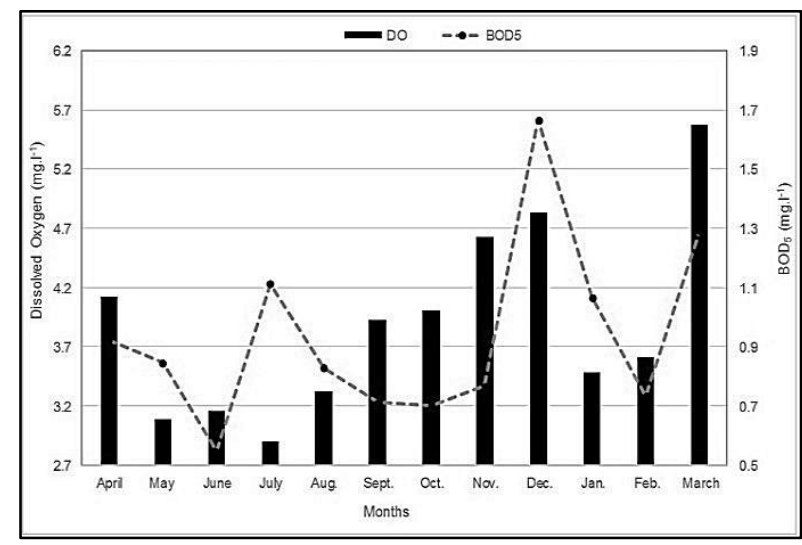

Fig.(3): Variations of $\mathrm{DO}$ and $\mathrm{BOD}_{5}$ content of water bodies during studied periods.

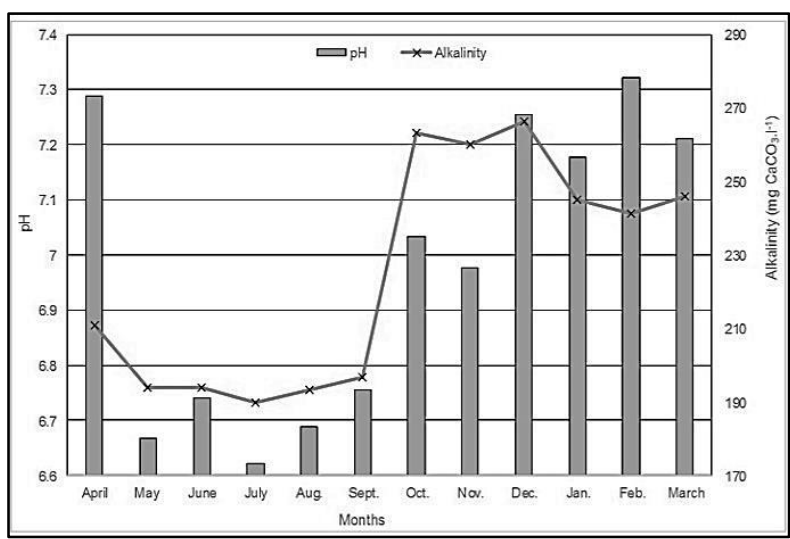

Fig.(4): Variations of $\mathrm{NO}_{2}, \mathrm{NH}_{4}$ and $\mathrm{PO}_{4}$ content of water bodies during studied periods.

Concentrations of ammonium, nitrite and phosphate during studied period were ranged between (1.4-22.3 $\left.\mu \mathrm{g} \mathrm{N} . \mathrm{NH}_{4} .^{-1}\right)$, (0.54-1.82 $\left.\mu \mathrm{g} \mathrm{N}-\mathrm{NO}_{2} \cdot 1^{-1}\right)$ and $\left(0.82-4.5 \mu \mathrm{gP}-\mathrm{PO}_{4} \cdot 1^{-1}\right)$ respectively Fig.(4), this variations may be due to nitrogenous organic matter decomposition by microbiological activity that take place in many surface and groundwater's. [37] commented that higher nutrients content occur in water polluted by sewage, fertilizers, agriculture wastes or industrial wastes containing organic nitrogen, free ammonia or ammonia salts, also they states that phosphate is an important guide of water characteristics and originate from different sources, especially the discharge of sewage effluent and agricultural runoff (fertilizers, waste from livestock). High concentrations of nutrients can result in eutrophication and algal growth, can significantly effect of aquatic ecosystem health, and went up ecological and recreational values of inland water resources [38]. However, agricultural discharge plays an important role in increasing concentrations of nitrates and nitrite resulting from the excessive use of fertilizers in agriculture, when microorganisms convert fertilizers, degraded plants, manure, animal manure or other organic waste [38].

\section{Multivariate Analysis}

PCA/Factor analysis was applied to fifteen variables for nine sites in twelve months during 2013-2014 based on the correlation matrix. Factors with eigenvalues more than 1 are regarded as significant. The factor loadings were remarkable as weak $(<0.5)$, moderate $(0.75<\mathrm{VF}>0.5) \quad$ and $\quad$ strong $\quad(\mathrm{VF}>0.5)$ corresponding to absolute varifactors values $[14,39]$. Table (2) summarized the results of PCA/FA, eigenvalues, a cumulative variance after rotated factors.

Depending on eigenvalues and varimax rotation only the first four factors explained more than $94 \%$ of the total variance for the data set. The first VF1 was represented with $43.43 \%$ of total variance and showed strong positive loading of $\mathrm{pH}, \mathrm{EC}, \mathrm{NO}_{2}, \mathrm{Na}$ and $\mathrm{K}$, while $\mathrm{PO}_{4}$ associated with moderate loading, on the other hand, negative moderate loading with $\mathrm{HCO}_{3}$. The presence of $\mathrm{EC}, \mathrm{Na}$ and $\mathrm{K}$ suggest mineral salts of around area. While, both nitrite and phosphate contributing to inorganic nutrients due to excessive influx of agricultural activities [12, 13]. In VF2, accounted for $23.59 \%$ the total variance and have strong positive loading with each of DO, $\mathrm{BOD}_{5}, \mathrm{Cl}$, acidity, and moderate positive loading on the $\mathrm{NH}_{4}$ and $\mathrm{PO}_{4}$ Fig.(5). This was represented by organic related variables 
(DO, BOD 5$)$, inorganic nutrients $\left(\mathrm{NH}_{4}, \mathrm{PO}_{4}\right)$ and physico- chemical source $(\mathrm{pH}, \mathrm{Cl})$ originated from domestic wastewater. VF3 constituted $16.5 \%$ of total variance, and it was weighted on both hardness and $\mathrm{Mg}$. This identified hardness related variables were mainly associated with nature of geological formation of the area [33]. The last VF4, explained with $10.58 \%$ of total variance and it is strong positive loading with $\mathrm{Ca}, \mathrm{HCO}_{3}$ and moderately loading with $\mathrm{Mg}$ Fig.(6). This factor can ascribed to chemistries naturally obtained by dissolution of carbonic rich sediments [10].

In the present study, Hierarchial agglomerative cluster analysis was applied on the normalized data set depending on the Wards method, by using Euclidean distances as a measure of similarity. The similarity between groups based on spatial and temporal variability of the water quality can be found out by cluster analysis, in addition to, discovering and understanding the intrarelation amongst variations parameters of the studied watershed [23]. The results of CA as shown in Fig.(7) yielded a dendogram of two clusters. Cluster one indicated that water

quality is hard type and it mainly influenced by geological formation of the area enriched with cations related to hardness. Cluster two, consists of two subgroups, first one revealed organic pollution from domestic wastewater, second subgroup, it is more related to domestic sewage water discharged into water bodies.

According to Fig.(8), two differentiated clusters were formed based on sites similarities. Cluster one consists of two subgroups, first one associated between sites 7 , 8 and 9 obtained represented streams well aerated water influenced by anthropogenic activities agricultural and domestic sewage. Second subgroup, binding to spring sites $(1,2$ and 4) more related to geological formation of the area. On the other hand, second cluster, identified similarity between site 5 (sulfur spring) and site 6 that influenced by it discharge.

As stated by [40] algae are considered to be excellent indicators of water quality, and certain species are capable of indicating water conditions. The algae occurred as in this study (springs and streams) which were listed alphabetically in Table (3).

Table (2)

Eigen value and percentage of variance explained by each of the four factor loading values for water quality variables of Koesenjaq water bodies.

\begin{tabular}{|c|c|c|c|c|}
\hline Variables & Factor 1 & Factor 2 & Factor 3 & Factor 4 \\
\hline Eigenvalue & 6.514 & 3.540 & 2.475 & 1.587 \\
\hline$\%$ total variance explained & 43.43 & 23.599 & 16.50 & 10.58 \\
\hline$\%$ cumulative variance & $\overline{43.43}$ & 67.029 & 83.529 & 94.109 \\
\hline \multicolumn{5}{|c|}{ Rotated factor correlation coefficients } \\
\hline $\mathrm{pH}$ & 0.903 & 0.400 & -0.028 & -0.097 \\
\hline EC & 0.950 & 0.012 & 0.224 & 0.022 \\
\hline DO & 0.472 & 0.787 & -0.125 & -0.261 \\
\hline $\mathrm{BOD}_{5}$ & -0.004 & 0.820 & -0.503 & -0.258 \\
\hline $\mathrm{HCO}_{3}$ & -0.599 & -0.091 & -0.027 & 0.736 \\
\hline Hardness & $\begin{array}{c}-0.003 \\
\end{array}$ & $\begin{array}{c}-0.080 \\
\end{array}$ & $\begin{array}{l}0.974 \\
\end{array}$ & 0.187 \\
\hline $\mathrm{Ca}$ & 0.116 & -0.471 & 0.012 & 0.864 \\
\hline $\mathrm{Mg}$ & 0.000 & 0.091 & 0.824 & -0.525 \\
\hline $\mathrm{Cl}$ & 0.146 & 0.803 & 0.015 & 0.526 \\
\hline Acidity & 0.055 & 0.869 & 0.114 & -0.203 \\
\hline $\begin{array}{l}\mathrm{NO}_{2} \\
\end{array}$ & $\begin{array}{l}0.877 \\
\end{array}$ & 0.331 & -0.257 & $\begin{array}{l}0.184 \\
\end{array}$ \\
\hline $\mathrm{NH}_{4}$ & -0.204 & 0.675 & 0.385 & -0.314 \\
\hline $\mathrm{PO}_{4}$ & 0.651 & 0.687 & -0.362 & -0.061 \\
\hline $\mathrm{Na}$ & 0.975 & -0.021 & 0.006 & -0.116 \\
\hline $\mathrm{K}$ & 0.981 & -0.139 & -0.077 & -0.008 \\
\hline
\end{tabular}




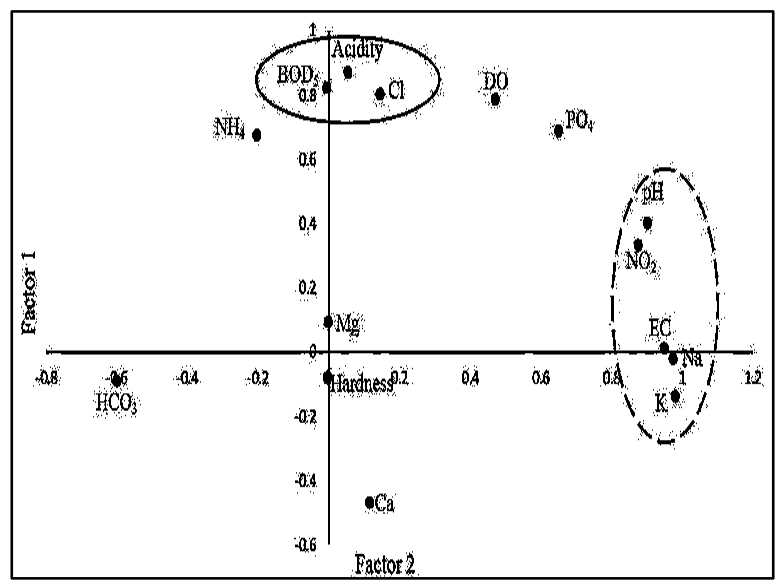

Fig.(5): Factor analysis scatterplot for water quality variables of Koesenjaq water bodies.

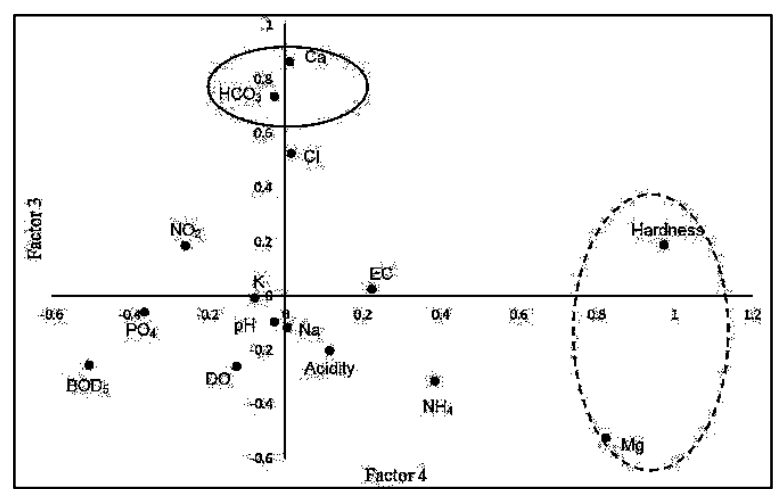

Fig.(6): Factor analysis scatterplot for water quality variables of Koesenjaq water bodies.

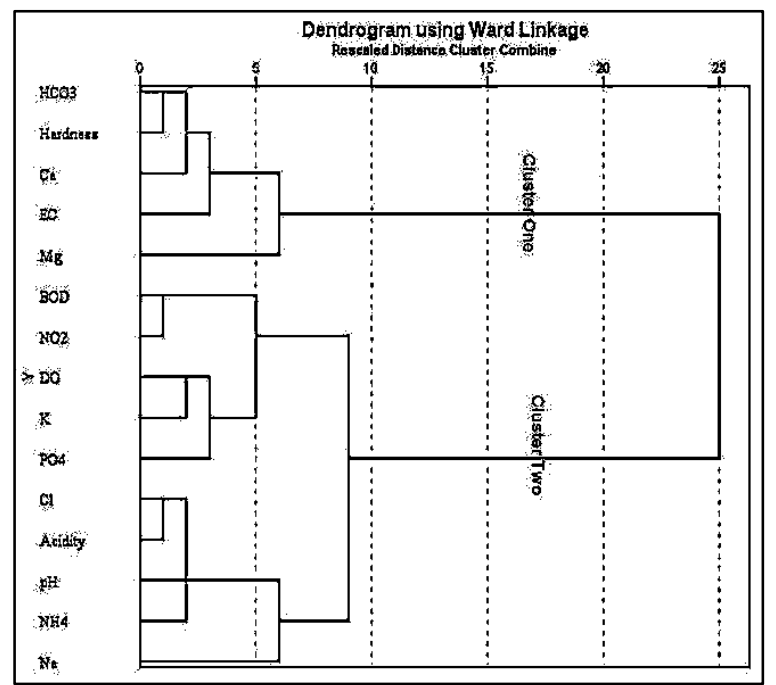

Fig.(7): Similarity dendogram among water quality variables for Koesenjaq water bodies from cluster analysis.

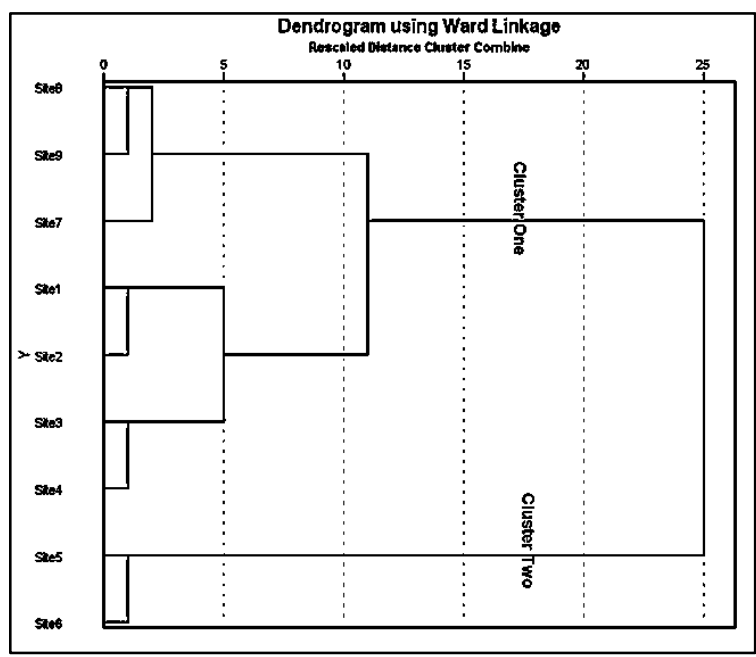

Fig.(8): Similarity dendogram between studied sites for Koesenjaq water bodies from cluster analysis.

During the course of this study, 73 species of algae were classified into the following seven categories: viz., Bacillariophyceae, Cyanophyceae, Chlorophyceae, Euglenophyceae, Charophyceae, Xanthophyceae and Rhodophyceae. Among this group Bacillallariophyceae (25 taxa) group dominated by Cyanophyceae (23 taxa), Chlorophyceae (16 taxa), Euglenophyceae (4 taxa), Charophyceae (2taxa), Xanthophyceae (2 taxa) and Rhodophyceae (1 taxa) Table (3). Changes in algae in this study are the results of their effect on the physical and chemical environment. Specimens that have been identified have a close relationship to the physiochemical conditions of currents and springs may be useful tools for the analysis of the ecological water quality index [41]. Monthly changes of algae showed higher density in summer which means that the temperature and light intensity hot months played an important role in increasing the concentration of phytoplankton [41]. Monthly variations of algae showed maximum density in summer which indicates that the temperature and light intensity of these months played an important role in increasing the population of phytoplankton [41]. In this survey, diatoms were the dominant algae and they had their best growth in spring and fall, while winter and summer periods mostly coincided with lower cell numbers. Water temperature and light have been reported as the most effective factors on seasonal developments of algae; however, other factors also affected the growth of algae [42]. 
Chlorophyta and Cyanophyta were other important algal groups in this survey. Although green algae have been recorded in samples in every season, they were richer in species composition in summer and winter when diatoms were represented with less species. Lyngbya spp. (5 taxa) and Oscillatoria spp. (6 taxa) were the richest genera in terms of species number. Oscillatoria spp. was the richest blue-green algal genus in species composition. The occurrence of the blue-green algae, especially Lyngbya spp., in summer and autumn was noticeable, thus supporting the Round [43] view's that the blue-green algae Lyngbya spp. and Oscillatoria spp. grow better and are more common especially in summer months. Blue-green algae play an important role not only with their property of growing very fast but also with their effects on aquatic environment and on other organisms in water. It has been recorded in many studies that bluegreen algae give out various metabolic substances in water [44].

Euglena sp. has been the most important genus in Euglenophyta as being represented with 4 taxa. The existence of Euglenophyta in water is a proof for the richness of water with organic substances [44]. This finding was supported with the present study since Euglena sp. showed better growth in summer and autumn when the concentration of organic matter in the pond water was higher in the ponds.

Table (3)

Shows list of algal species identified from studied sites in Koesenjaq subdistrict.

\begin{tabular}{|c|c|c|c|c|c|c|c|c|c|}
\hline Algal record & 1 & 2 & 3 & 4 & 5 & 6 & 7 & 8 & 9 \\
\hline \multicolumn{10}{|l|}{ Cyanophyta } \\
\hline \multicolumn{10}{|l|}{ Order: Chroococcales } \\
\hline Chroococcus minor (Kutzing) Nageli & + & & & & & & & + & \\
\hline C. Minutus (Kutzing) Nageli & & & & & & & & \pm & \\
\hline C. Tenax (Kirchn.) Hieron & & & & & & & & + & + \\
\hline Merismopedia punctata Meyen & & + & & & & & + & + & + \\
\hline \multirow{2}{*}{\multicolumn{10}{|c|}{ Order: Oscillatoriales }} \\
\hline & & & & & & & & & \\
\hline Lyngbya digueti (Gomont) & & & & + & & + & & & \\
\hline L. kuetzingii Schmidle & + & & & & & & & & \\
\hline L. Jachneri (Zimm.) Geitler & & + & + & & & & & & \\
\hline L. martensiana (Meneghini) & + & & + & + & & & & & \\
\hline L. nordgardhii Wille & & & & + & + & & & & \\
\hline \multicolumn{10}{|l|}{ Oscillatoria formosa Bory } \\
\hline O. limnetica Lemmermann & & & + & & & & + & + & + \\
\hline O. limosa Roth Agardh & & & & & + & & & \pm & \\
\hline O. pseudogeminata G. Schmid & & & & & & & & + & \\
\hline O. terebriformis Agardh & & + & & & & & + & + & + \\
\hline O. tenuis Agardh & + & & + & & + & + & + & & + \\
\hline Phormidium ambiguum Gomont & & & + & & & + & & & + \\
\hline P. Cebennens Gomont & + & & & + & & & & & \\
\hline \multicolumn{10}{|l|}{ Spirulina laxissima G.S. West } \\
\hline S. subtilissima (Kutzing) Gomont & & & + & & & & & + & \\
\hline \multicolumn{10}{|l|}{ Order: Nostocales } \\
\hline Calothrix paraietina (Thuret) & + & & & + & & + & & & \\
\hline Homeothrix janthiana (Born and Flah.) & & & & + & + & & & & \\
\hline H. julliana (Born and Flah.) Kirchner & \pm & & & & + & & & & \\
\hline \multicolumn{10}{|l|}{ Chlorophyta } \\
\hline \multicolumn{10}{|l|}{ Order: Chlorococcales } \\
\hline Scenedesmus bijuga (Turp) Lagher & & & & + & & & & + & \\
\hline Polmodictyon varium (Noeg.) Lemm. & \pm & & & + & & & & & \\
\hline \multicolumn{10}{|l|}{ Order: Ulotrichales } \\
\hline Ulothrix rorida (Thuret) & & & + & & & & & + & \\
\hline$U$. variabilis (Kutzing) Kutzing & & + & & + & & \pm & & & \\
\hline \multicolumn{10}{|l|}{ Order: Chaetophorales } \\
\hline Stigeoclonium pachydermum Prescott & & & & & & + & & & \\
\hline \multicolumn{10}{|l|}{ Order: Oedogoniales } \\
\hline Oedogonium sp. & & + & & + & + & & + & & \\
\hline \multicolumn{10}{|l|}{ Order: Zygnematales } \\
\hline \multicolumn{10}{|l|}{ Closterium peracerosum (Naegel) } \\
\hline C. moniliform & + & + & & & & & + & + & + \\
\hline \multicolumn{10}{|l|}{ Cosmarium laeve Rabenhorst } \\
\hline C. pracmctsum Brebisson & + & + & + & & + & & + & + & + \\
\hline Spirogyra longata & & & + & + & & & & + & \\
\hline S. rivularis & & & + & & & & & & + \\
\hline Spirogyra $s p$. & & + & & & & & + & & \\
\hline Zygnema sp. & & & + & + & & & & & $\overline{+}$ \\
\hline Mougeotia sp. & & + & & + & + & & + & & + \\
\hline \multicolumn{10}{|l|}{ Order: Cladophorales } \\
\hline Cladophora glomerata (L.) Ktz. & & + & & & & + & + & + & \\
\hline \multicolumn{10}{|l|}{ Charophyta } \\
\hline \multicolumn{10}{|l|}{ Order: Charales } \\
\hline Chara canescens Desvaux and Lois & & & & & & & & & \\
\hline C. Vulgaris Linnaeus & & & & & & & & & \\
\hline
\end{tabular}




\begin{tabular}{|c|c|c|c|c|c|c|c|c|c|}
\hline Algal record & 1 & 2 & 3 & 4 & 5 & 6 & 7 & 8 & 9 \\
\hline Euglenophyta & & & & & & & & & \\
\hline Order: Euglenales & & + & & & & & & & + \\
\hline Euglena gracilis Klebs & & & & & & & & & + \\
\hline Phacus acuminatus Stoken & & & & & & & & + & \\
\hline P. orbicularis Hnebner & & + & + & & & & & & \\
\hline P. plenuronectes (Muell.) Dujardin & & & & & & & & + & \\
\hline Chrysophyta & & & & & & & & & \\
\hline Class: Xanthophyceae & & & & & & & & & \\
\hline Order: Vaucheriales & & & & & & & & & \\
\hline Vaucheria geminata (Vouch.) de Candolle & & & & + & & + & & & \\
\hline V. sessilis (Vouch.) de Candolle & & & & & & & \pm & \pm & \pm \\
\hline Class: Bacillariophyceae & & & & & & & & & \\
\hline Order: Centrales & & & & & & & & & \\
\hline Family: Cosinodiscineae & & & & & & & & & \\
\hline Melosiraceae & & & + & + & + & + & + & + & + \\
\hline Melosira varians Ag. & & & & & & & & & \\
\hline Order: Pennales & & & & & & & & & \\
\hline Suborder: Araphidineae & & & & & & & & & \\
\hline Family: Fragilariaceae & & & & & & & & & \\
\hline Fragilaria crotonensis Kitton var. crotonensis & & & & & & \pm & & & \\
\hline F. vaucheriae (Kutz.) petrs. var. vaucheriae & & & + & & & & & + & + \\
\hline$F$. virescens Ralf & + & + & & + & + & + & & + & + \\
\hline Synedra ulna Eh. var Ulna & & + & + & + & + & & + & + & \\
\hline S. acus Kutz. var. acus & + & + & & & & + & & + & + \\
\hline Diatoma vulgare Bory & & + & & & & & & & + \\
\hline Suborder: Biraphidineae & & & & & & & & & \\
\hline Family: Naviculaceae & & & & & & & & & \\
\hline Diplonies ovalis (Hilse.) $\mathrm{Cl}$ & & & & & \pm & & & + & \\
\hline Frustulia rhomboides (var. saxionica) & + & & & & + & & + & + & \\
\hline Gyrosigma acuminatum. var. a cuminatum & & & + & & & & & + & + \\
\hline Na vicula canalis var. canalis Patr. & + & + & & & & & & & \\
\hline N. gracilis Ehr. & & & + & & & + & & + & \\
\hline N. rhyncocephala var. rhyncocephala Kutz. & & & + & & & & & + & \\
\hline N. viridula (Ktz.) Ehr. & + & & + & & & & & & \\
\hline Family: Cymbellaceae & & & & & & & & & \\
\hline Amphora ovalis Kutz. var. ovalis & & & + & + & + & + & & + & \\
\hline Cymbella minuta var. minuta Hilsc & & & + & + & + & + & & & \\
\hline C. minuta Var. silesica Rcim & & & + & & + & & & & \\
\hline Family: Epithemiaceae & + & & & + & & & + & + & \\
\hline Denticula elegans var. elegans Kutz. & & & & & & & & + & \\
\hline D. elegans var. kittoniana (Grun.) De T. & & & & & & & & & \\
\hline Roicosphenia aurvata (Kutz.) Grun & & & & & & & & + & \\
\hline Rhopalodia gibba (Her.) V. Mull. var. gibba & & & \pm & \pm & + & & & + & \\
\hline R. parallela var. parallela (Grun.) & & & & & & + & & & \\
\hline Suborder: Monoraphidineae & & & & & & & & & \\
\hline Cocconies pediculus Ehrenberg & & & + & + & + & & & + & + \\
\hline C. placentula Ehrenberg & & + & & & & & & & \\
\hline C. pla centula var. lineata (Ehr.) V.H. & & & & & & & & & + \\
\hline Rhodophyta & & & & & & & & & \\
\hline Order: Nemalionales & & & & & & & & & \\
\hline Batrachospermum gelatinosum (Linna eus) de & & & & + & & & & & \\
\hline
\end{tabular}

\section{References}

[1] Burnham, G.; Lafta, R.; Doocy, S.; Roberts, L.; "Mortality after the 2003 Invasion of Iraq: A cross-sectional cluster sample survey" Lancet, 368, 9545, 14211428. 2006.

[2] Bonanno, G.; Giudice, R. "Application of two quality indices as monitoring and management tools of rivers. Case study: the
Imera Meridionale River, Italy" Journal of Environ Manage Vol, 45, pp: 856-67, 2010.

[3] Diersing, N. "Water Quality: Frequently Asked Questions" Florida Brooks National Marine Sanctuary; Key West, FL; 2009.

[4] Alobaidy A. H.; Maulood, B. K.: Kadhem A.J.; "Evaluating Raw and Treated Water Quality of Tigris River within Baghdad by Index Analysis"; Journal of Water Resource and Protection; 2(7), 629-635; 2010. 
[5] Altansukh, O.; Davaa, G.; "Application of Index Analysis to Evaluate the Water Quality of the Tuul River in Mongolia," Journal of Water Resources and Protection; 3(6); pp. 398-414; 2011.

[6] Chapman, D.; "Water Quality Assessment: A Guide to Uses of Biota, Sediments and Water in Environmental Monitoring", $2^{\text {nd }}$ Ed.; Great Britain at University Press; Cambridge; 1996.

[7] AL-Janabi, K. W.; Alazawi, F. N.; Mohammed,M. I.; Kadhum, A. A.; Mohamad, A. B.; "Chlorophenols in Tigris River and Drinking Water of Baghdad, Iraq"; Bulletin of Environmental Contamination and Toxicology; 87(2); 106$112 ; 2011$.

[8] Altansukh, O.; Davaa, G.; “Application of index analysis to evaluate the water quality of the Tuul River in Mongolia"; Journal of Water Resour Prot; 3, 398-414; 2011.

[9] Al-Hamdani, F.Z.; "Water pollution in Iraq between disastrous border and no real solutions. A study"; Journal of Genet Environ Res Conserved; 1(2), 111-8; 2013.

[10] Mu, X.; Brower, J. C.; Siegel, D. I.; Fiorentino, A. J.; An, S. and Jiang, H.; "Using integrated multivariate statistics to assess the hydrochemistry of surface water quality, Lake Taihu basin, China"; Journal Limnology; 74(2), 234-247, 2015.

[11] Muangthon, S.; "Assessment ecosystem of the Lamtakong River Basin (Thailand) using multivariate statistical techniques"; Review of Integrative Business and Economics Research; 4,198- 216; 2015.

[12] Zabihollah, Y.; Ahmad, T.; Kamran, N.; Younis, Y. and Aliakbar, Y.; "Assessment of the surface water quality in Tajan River basin, Iran"; Life Science Journal; 10(3), 775- 780; 2013.

[13] Gu, Q.; Zhang, Y.; Ma, L.; Li, J.; Wang, K.; Zheng, K.; Zhang, X.; Sheng, L.; "Assessment of reservoir water quality using multivariate statistical techniques: A case study of Qiandao Lake, China"; Sustainability; 8(243), 1-17; 2016. doi:10.3390/su803 0243.

[14] Sabri, N. A.; Abdullah, M. P.; Mat, S.; Elfithri, R.; Khalik, W. M. A. "Evaluation of hydrochemistry variation in water quality of Cempaka lake, Malaysia using multivariate statistical analysis" Journal Mater. Environ. Sci.; 7(12), 4403-4410; 2016.

[15] APHA; "Standard Methods for the Examination of Water and Wastewater"; $20^{\text {th }} \mathrm{Ed}$; APHA, Washington, DC.; 1998.

[16] Rump, H. H. "Laboratory Manual for the Examination of Water Wastewater and Soil"; Federal Republic of Germany; 225pp; 1999.

[17] Parsons, T. R.; Maita, Y.; Lalli, C. M.; "Manual of Chemical and Biological Methods for the Seawater Analysis"; Pergman Press; Oxford; 360pp; 1984.

[18] Desikachary, T. R.; "Cyanophyta. Indian Concil of Agriculture Research"; 686 pp; 1959.

[19] Prescott, G. W.; "Algae of the Western Great Lake Area"; W. B. Co. Publ.; 977 pp.; 1979.

[20] Smith, G. M.; "The Fresh Water Algae of United States"; McGraw-Hill; 917 pp.; 1950.

[21] Shrestha, S.; Kazama, F.; "Assessment of surface water quality by using multivariate statistical techniques: A case study of the Fuji River basin, Japan"; Environ Model Software; 22(4); 464- 475. 2007.

[22] Vega, M.; Pardo, R.; Barrado, E.; Deban, L.; "Assessment of seasonal and polluting effects on the quality of river water by exploratory data analysis"; Water Research, 32; 3581- 3592; 1998.

[23] Pejman, A.H.; Nabi Bidhendi, G.R.; Karbassi, A.R.; Mehrdadi, N. and Esmaeili Bidhendi, M. "Evaluation of spatial and seasonal variations in surface water quality using multivariate statistical techniques"; International Journal of Environmental Science and Technology; 6(3); 467- 476; 2009.

[24] Ahipathy, M.V.; Puttaiah, E.T.; "Ecological Characteristics of Vrishabhavathy River in Bangalore (India) "; Environmental geology; 49(8); 1217$1222 ; 2006$.

[25] Al-Obaidy, A.H.M.J.; Bahram, K.M.; Abass, J.K.; "Evaluating Raw and Treated Water Quality of Tigris River within Baghdad by Index Analysis"; Journal Water Resource and Protection, 2; 629- 635; 2010. 
[26] Maulood, B.K.; Hinton, G.C.F.; Kamees, H.S.; Saleh, F.A.K. ; Shaban, A.A.; AlShahwani, S.M.H.; "An Ecological Survey of Some Aquatic Ecosystems in Southern Iraq"; Tropical Ecology; 20(1); 27-40; 1979.

[27] Al-Saadi, H.A.; Kassim, T.I.; Al- Lami, A.A.; Salman, S.K.; "Spatial and Seasonal variations of phytoplankton populations in the upper region of the Euphrates River, Iraq"; Limnologica, 30; 83-90; 2000.

[28] Iraqi Drinking water quality standards; "Environmental Legislation (Iraqi standards), Iraqi Directorate for Environmental Protection and Improvement"; Ministry of Health, Baghdad, Iraq; 1986.

[29] WHO; Guidelines for drinking water quality"; $4^{\text {th }} \mathrm{Ed}$; NML. Classification; WA 675; 541pp; 2011.

[30] Ruttner, F.; "The Fundamental of Limnology"; Univ. of Tornto Press; 295pp; 1973.

[31] Charles E. Reen. (1970). "Investigating Water Problems: A Water Analysis Manual"; Publishing by LaMotte Chemical Products Company, Chestertown, Maryland. 72pp.

[32] Tebbutt, T.H.Y.; "Principles of water quality control"; $3^{\text {rd }}$ Ed; Pergamon Press; UK; 235pp.; 1983.

[33] Shekha, Y. A.; "Evaluation of water quality for Greater Zab River by principal component analysis/ factor analysis"; Iraqi Journal of Science;57 (4B); 2650-2663; 2016.

[34] Yisa, J and Jimoh., B.; "Analytical Studies on Water Quality Index of River Land-zu," American Journal of Applied Sciences, 7(4), pp. 453-458; 2010.

[35] Boyd, C.E.; "Water Quality an Introduction"; Kluwer Academic Publishers, Boston, USA, 330p.; 2000.

[36] Twort, A.C.; Law, F. M.; Crowley, F.W.; "Water Supply". $3^{\text {rd }}$ Ed; Thomson Litho Ltd, East Kill bride Scotland; 338 pp.; 1985.

[37] Bartram, J.; Balance, R.; "Water quality monitoring (a practical guide to the design and implementation of freshwater quality studies and monitoring programmes). UN Environmental Programme- UNEP- and
WHO; E and FN Spon, Chapman and Hall; UK. 383pp.; 1996.

[38] Davis, J.R.; Koop, K.; "Current understanding of the eutrophication process in Australia"; In Schumann, A.H.; Acreman, M.C.; Davis, R.; Marino, M.A.; Rosbjerg, D.; Jun, X.; (eds.) "Regional management of water resources"; International Association of Hydrological Sciences; Wellingford, Oxford shire; 2001.

[39] Liu, W. C.; Lin, K. H. and Kuo, Y. M.; "Application of factor analysis in the assessment of groundwater quality in a blackfoot disease area in Taiwan". The Science of the Total Environment. 313(1); 77- 89; 2003.

[40] Wilcock, R. J; McBride, G. B.; Nagels J. W.; Northcott ,G. L.; "Water Quality in a Polluted Lowland Stream with Chronically Depressed Dissolved Oxygen: Causes and Effects," New Zealand Journal Marine and Freshwater Research; 29(2), pp; 277-288; 1995.

[41] Lacerda, S.R.; Koening, M.L.; NeumannLeitao, S.; Flores-Montes, M.J.; "Phytoplankton nyctemeral variation at a tropical river estuary (Itamaracá Pernambuco - Brazil”. Brazilian Journal of Biology; 64; 81-94; 2004.

[42] Lund, J. W. G.; "The Ecology of the Freshwater Phytoplankton"; Biological Reviews; 40, 231-293; 1965.

[43] Round, F. E.; "The Ecology of Algae"; Cambridge University Press, Cambridge, U.S.A., 653 pp.; 1981.

[44] Fogg, G. E. "Extracellular products of algae in freshwater". Arch. Hydrobiol., 5; $1-2 ; 1971$. 